\title{
SiM
}

\section{Use of Rotational Stocking in Combination With Cultural Practices for Smutgrass Control-A Florida Case Study}

\author{
By Joseph H. Walter, Yoana C. Newman, Sharon F. Gamble, Dennis M. Mudge, \\ Pete Deal, Matheus Baseggio, and Ashley Fluke
}

\section{On the Ground}

- Smutgrass (Sporobolus indicus) is an invasive plant in Florida sandy soils, prevalent in central and south Florida where temperatures seldom drop below freezing and hard frost events are infrequent.

- Smutgrass becomes nonpalatable to cattle as it matures and cattle avoid grazing it after the emergence of seed stalks and when leaves become tough. However, young smutgrass growth is palatable to cattle.

- High stocking densities in combination with severe defoliation have proven deleterious for this grass. This study evaluated the use of increased stock density and rotational grazing management for 3 years following a one-time defoliation by mowing or burning smutgrass infested pastures.

Keywords: rotational stocking, smutgrass, prescribed burning, mob grazing, integrated pest management, IPM.

Rangelands 35(5):98-103

doi: 10.2111/RANGELANDS-D-13-00023.1

(C) 2013 The Society for Range Management

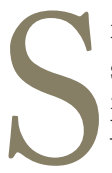

mutgrass (Sporobolus indicus) is a perennial warmseason bunch grass native to tropical Asia and an invasive weed in pasture areas and roadsides in the United States. In Florida, the site of the 67th Society for Range Management Annual Meeting, ${ }^{\mathrm{i}}$ it ranks as a

\footnotetext{
The 67th SRM Annual Meeting, From Dusty Trails to Waning Wetlands, will be held in Orlando, Florida, USA, 8-13 February 2014. Join us there to learn more about Florida rangelands. For more information on the 2014 SRM Annual Meeting, see http://www.rangelands.org/events/.
}

top weed because of the poor palatability, prolific seed production, adaptation to infertile sandy soils, and challenges to keep it from spreading. In Florida, greater than half the pastures planted to bahiagrass (Paspalum notatum) are invaded by this weed. Two types of Smutgrass are found in the state, a small type (var. indicus) and a giant type (var. pyramidalis). ${ }^{1}$ The small type is found throughout the state, and the giant smutgrass is prevalent in south and central Florida, with invasion increasing toward north Florida. ${ }^{2}$

Smutgrass has a short growth cycle with profuse seed production of approximately 45,000 seeds per plant. ${ }^{2}$ Flowering and seed production is not limited by day length or temperature. Consequently, each smutgrass plant is capable of flowering and producing seed throughout the year. Unlike the forage grasses commonly grown on Florida ranches, smutgrass will likely extend growth throughout the winter and early spring if soil moisture is adequate. This provides smutgrass a competitive advantage over grasses that become dormant or semidormant during the winter. The prolific seed production of smutgrass rapidly results in infestation levels that significantly reduce forage production of pastures and reduce beef yields.

Effective chemical control of smutgrass exists; however, this treatment requires a significant amount of capital, labor, and equipment, and is effective in Florida only during the summer months when ample rainfall can be expected. A chemical treatment option is hexazinone (Velpar), which has negative effects on nontarget species, especially oak trees, and is a potential source for ground and surface water contamination. At the beginning of this project, label restrictions prevented grazing for 60 days postapplication of Velpar for smutgrass control. Several chemical alternatives have been tried for control of smutgrass in warm-season perennial pastures, but selective control has proven difficult., ${ }^{3,4}$ In bahiagrass pastures, hexazinone is not cost effective until infesta- 
tions densities are greater than $50 \%$ of ground cover. ${ }^{2}$ Another option tested is the mowing of smutgrass plants treated with herbicide, but, despite some increased control, ${ }^{1}$ it is regarded as an unnecessary expense. ${ }^{5}$

Smutgrass responds rapidly following defoliation. In addition, cattle have been observed to readily consume the regrowth soon after defoliation by burning or mowing. At early stages of growth, the crude protein and digestibility of smutgrass is comparable to bahiagrass. ${ }^{2}$ This provides an opportunity for ranchers to utilize smutgrass as forage during a period when other forages are dormant or nearly so. As the leaf tissue ages and seed stalks appear, cattle begin to avoid grazing smutgrass and consume other plants. This often results in the overgrazing of bahiagrass, reducing its vigor and yields, and in turn resulting in greater infestations of weeds, including smutgrass.

When intensively grazed, smutgrass is consumed by cattle, with cattle weight gain that is similar to that of bahiagrass. ${ }^{6}$ Cattle have been shown to consume smutgrass early in the year and 2 weeks after mowing or burning. Our study was based on the rationale that increased stocking density following the initial defoliation treatments would i) decrease forage plant selectivity of animals, ii) increase consumption of smutgrass early regrowth, and iii) provide recovery from grazing events for bahiagrass and limpograss (Hemarthria altissima). Our objectives were to compare the effects of mowing or burning treatments followed by increased stocking density on smutgrass cover and density.

\section{About the Project}

This project is the result a "grass roots effort" initiated by two cattle ranching operations, the USDA Natural Resources Conservation Service (NRCS), several county Extension offices, and specialists at University of Florida, in search for alternative method to herbicide use for control of the weed smutgrass. Our primary goal was to demonstrate that defoliation of smutgrass plants and increased stock density could be used to reduce the extent of the smutgrass problem on cattle ranches without disrupting normal management activities. Secondary goals included:

1) Reducing the vigor of smutgrass plants,

2) Comparing the effect of treatments on the number and size of smutgrass plants,

3) Reducing the number of smutgrass plants reaching maturity and producing seed, and

4) Maintaining acceptable body condition and weight gain on grazing animals.

The project was located on a commercial cattle ranch in southern Brevard County, FL (Fig. 1). The soils in the project area are mapped as Riviera Sand. These soils are in the forage suitability group "Sandy over loamy soils on flats of hydric or mesic lowlands" (G156BC241FL). Expected yields of bahiagrass in this forage suitability group range

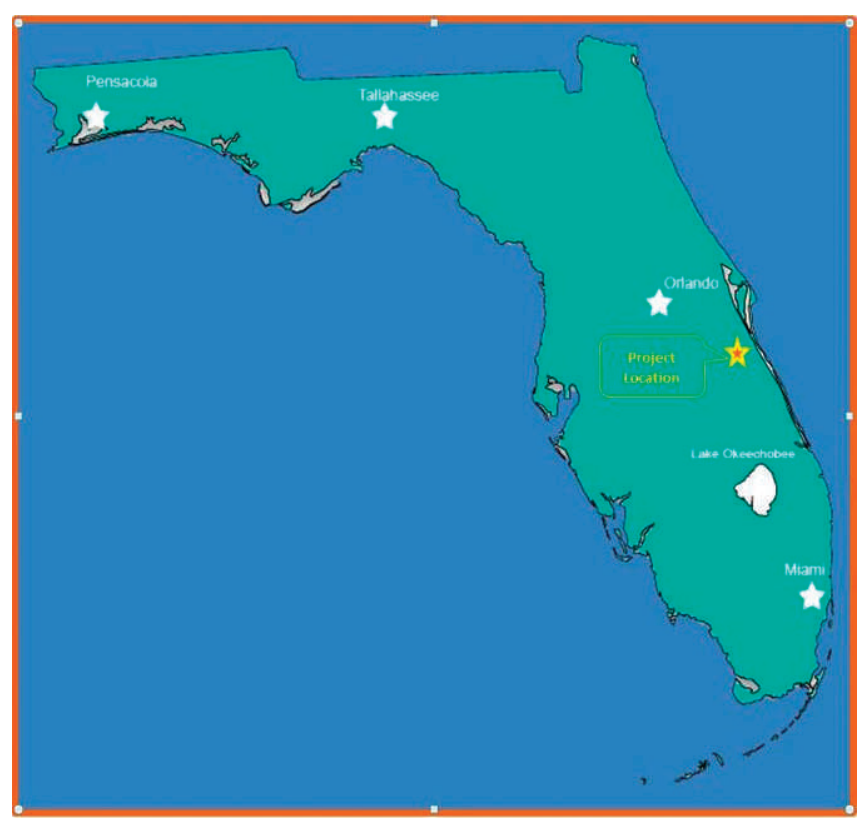

Figure 1. Location of the project in Florida, USA.

from 8,750 to 10,000 pounds of dry matter per acre. ${ }^{7}$ Yields of limpograss range from 10,000 to 13,000 pounds of dry matter per acre. ${ }^{7}$ This is a poorly drained, nearly level soil on broad, low flats. This soil has a water table within a depth of 10 inches for 2 to 4 months in most years and at a depth of 10 to 30 inches for most of the rest of the year; available water holding capacity is low in the surface and subsurface layers. Unless limed, the surface layer ranges from extremely acidic to slightly acidic.

The project area contained approximately 56 grazeable acres. The site was bordered on the north and west sides by a deep drainage canal. Shallow ditches used to remove excess nuisance water bisected the treatment area. The shallow ditches also formed the boundaries for the 12 treatment blocks. The average size of the treatment blocks was approximately 4.5 acres.

Three different treatments were applied and randomly assigned to the blocks: prescribed burning, mowing, and a control. The control treatment was not burned or mowed. These treatments were replicated four times (Fig. 2).

Initial smutgrass infestation occurred in dense colonies scattered across the project area. These colonies were not evenly distributed across the project area. The foliar cover composed of smutgrass ranged from $20 \%$ to $30 \%$ in the northernmost treatment blocks to more than $50 \%$ herbage cover in the southernmost treatment blocks (Fig. 2).

Mowing and burning were done in November 2009 only after the warm-season grasses were dormant. The ditches on each side of the burn blocks were used as fire breaks. Head fires were used on burn treatments. The mowed blocks were cut to an 8-inch stubble height with a bush hog style rotary mower. Original plans to mow the blocks to a low 4- to 


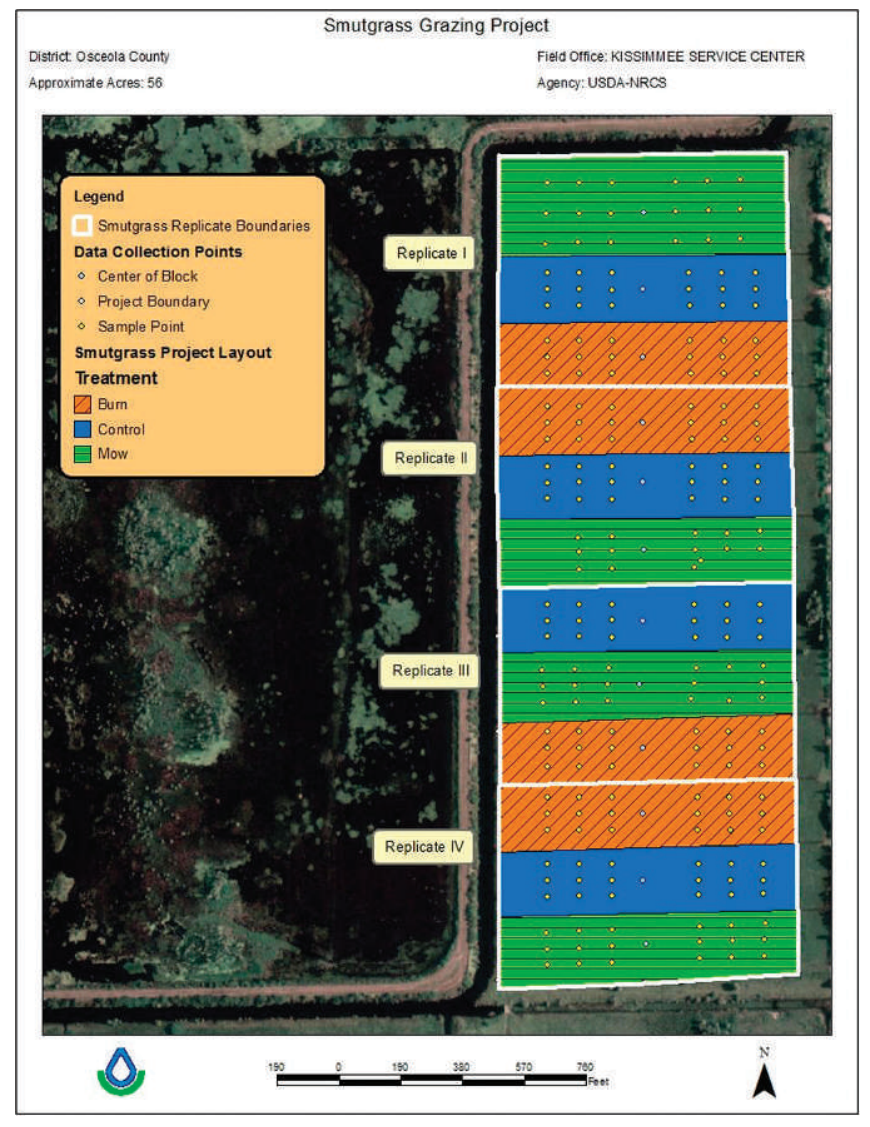

Figure 2. Layout of the treatments in Deseret Ranch project area.

5-inch stubble height was not possible because the mass of dead smutgrass plugged the mower.

Plants were counted and measured about 1 week after the mowing and burning was completed. We counted the number of plants that occurred in each $4 \mathrm{~m}^{2}$ quadrat. In addition, we measured the circumference of each plant in the quadrat. The plants were measured again in late November or early December for 3 years after treatments had been applied. The initial measurements were taken on 23 November 2009 and yearly after that on 15 December 2010, 30 November 2011, and 19 December 2012.

Initially we had planned to have 18 sampling points in each treatment block. However, two treatment blocks contained wetlands that forced us to reduce the number of sampling points in those blocks. We laid out the sampling points in a grid using a tape measures and pin flags. The location of each sampling point was recorded using GPS equipment provided by the NRCS. We used the GPS devises to eliminate the need to place permanent markers at each sampling point. The GPS Data points were then imported into the NRCS ArcGis software to generate maps. The GPS equipment was also used to relocate the sampling points in each year the treatments were monitored.

\section{Grazing Management}

Deseret Cattle and Citrus donated use of the site and constructed approximately 2,600 feet of barbed wire fence.

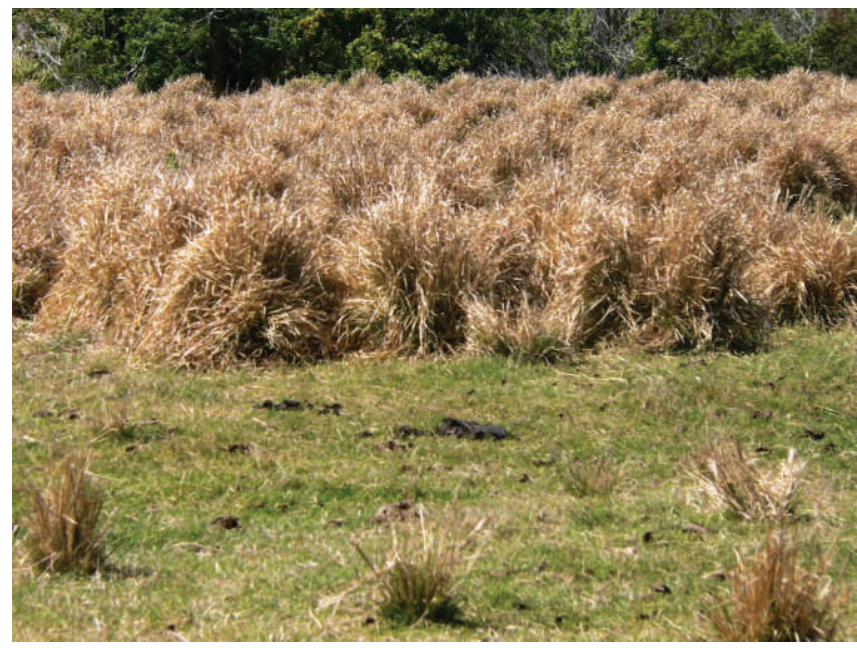

Figure 3. Overgrazed bahiagrass and ungrazed smutgrass. Notice only isolated smutgrass plants showed evidence of grazing.

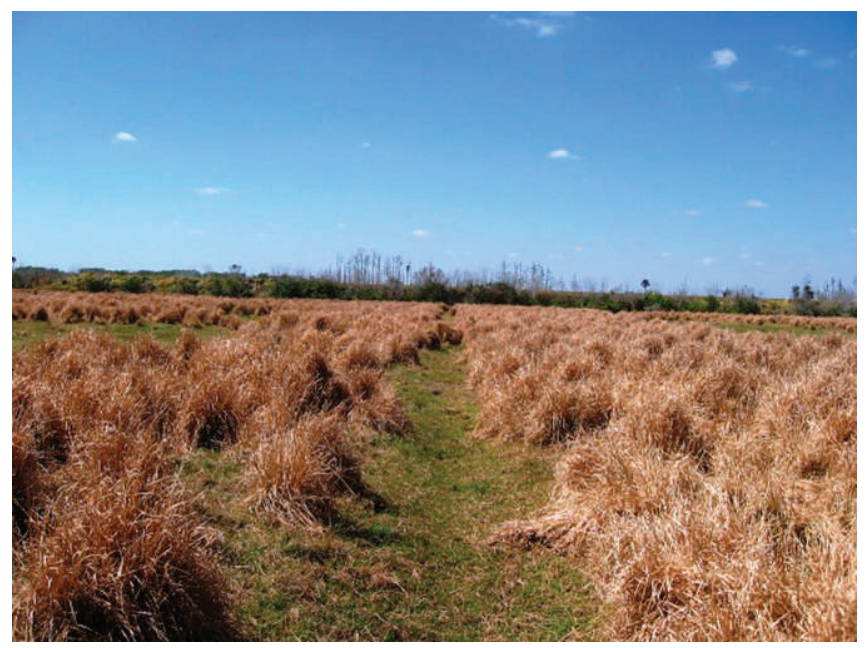

Figure 4. Spot grazing in ditch between treatment blocks. Notice the absence of grazing on smutgrass plants.

The ranch prefers to use a low-intensity rotational grazing system. The typical grazing animal is a Brahman cross cow weighing about 1,200 pounds $(544 \mathrm{~kg})$. Stocking rates are kept low to reduce the need for supplemental feed during the winter and spring periods. The traditional stocking density for this area is generally below 3 animal units (AU) per acre $(7.4 \mathrm{AU} / \mathrm{ha})$. Construction of the fence allowed the ranch to increase the stocking density to as high as $7.1 \mathrm{AU}$ per acre (17.5 AU/ha).

Spot grazing was recognized as a problem during the planning. In March of 2009 it was observed that the cattle were grazing the more palatable grasses as short as they could and avoided grazing the smutgrass. Figures 3 and 4 show examples of the spot grazing and the large mass of ungrazed smutgrass.

Table 1 shows the number of grazing events, stock density, length of the grazing periods, total number of grazing 
Table 1. Number of grazing events, stock density, length of the grazing periods, total number of grazing days, and animal unit months per acre each year

\begin{tabular}{|c|c|c|c|c|c|c|c|}
\hline \multirow{2}{*}{ Year } & \multirow{2}{*}{$\begin{array}{l}\text { Number } \\
\text { of grazing } \\
\text { events }\end{array}$} & \multicolumn{3}{|c|}{$\begin{array}{l}\text { Stock density (animal units per } \\
\text { acre) }\end{array}$} & \multirow{2}{*}{$\begin{array}{l}\text { Average length } \\
\text { of grazing } \\
\text { periods }\end{array}$} & \multirow{2}{*}{$\begin{array}{l}\text { Total } \\
\text { grazing } \\
\text { days }\end{array}$} & \multirow{2}{*}{$\begin{array}{l}\text { Animal unit } \\
\text { months per } \\
\text { acre per year }\end{array}$} \\
\hline & & High & Low & Average & & & \\
\hline 2010 & 12 & 6.5 & 3.0 & 5.32 & 5 & 17,041 & 10.0 \\
\hline 2011 & 8 & 7.1 & 1.7 & 5.27 & 10 & 15,016 & 8.8 \\
\hline 2012 & 8 & 3.4 & 1.7 & 2.41 & 15 & 15,456 & 9.1 \\
\hline Average & 9.3 & & & 4.33 & 9 & & 9.3 \\
\hline Total & & & & & & 47,513 & \\
\hline
\end{tabular}

days, and animal unit months per acre each year. The change in management is most noticeable in the number and length of grazing periods. During the first year, the site was grazed more frequently than it was grazed in the second and third years after treatment. The length of the grazing periods was also much shorter during the first year.

The plan was to have the cattle graze the smutgrass plants frequently enough to reduce the opportunity for the smutgrass to mature and become unpalatable. This was accomplished in the first year after treatment. Grazing events were more frequent during the first year and only one recovery period following grazing exceeded 40 days. In year 2, the number of grazing events declined by $50 \%$ and there were two instances when the recovery period exceeded 40 days. The number of grazing events remained low in year 3 , and one recovery period exceeded 40 days.

In year 1 (2010), the average length of the grazing events was 5 days. The first grazing event occurred approximately 7 days after the burn treatments were completed. The second grazing event began on 7 December, approximately 20 days after the burn. Both of these events were less than 4 days long. The third grazing event occurred on 12 January and lasted 14 days. The site was grazed for 3 days beginning on 17 February (Fig. 5). The fifth grazing event began on 12 April and lasted 3 days. After that, the grazing events occurred every 20 to 39 days until December, 2010. The site was not grazed for 88 days following the December, 2010 event.

In year 2 (2011), there were eight grazing events. Five of the events were less than 4 days in length. Three of the events were longer than 14 days. The average length of the grazing events in year 2 increased to 10 days. The rest or recovery period averaged 30 days. However, the recovery periods ranged from 19 to 61 days.
In year 3, (2012) the site was also grazed eight times. The average length of the grazing events increased to 15 days. Only three of these grazing events were 7 days or less. The rest of the grazing events ranged from 12 to 24 days in length. The average recovery period during year 3 was 29 days in length and ranged from 24 to 86 days.

Stocking density also varied by year due to the effects of weather and management changes. In year 1 the stocking density was consistent at or above $3.0 \mathrm{AU}$ per acre. The highest stocking density was 6.5 and the average for the first year was 5.32. In year 2, the stocking density ranged from 1.7 to $7.1 \mathrm{AU}$ per acre and averaged 5.27 AU per acre. Year 3 had the lowest stocking density. During this period the stocking density ranged from 1.7 to $3.4 \mathrm{AU}$ per acre and averaged 2.41 $\mathrm{AU}$ per acre.

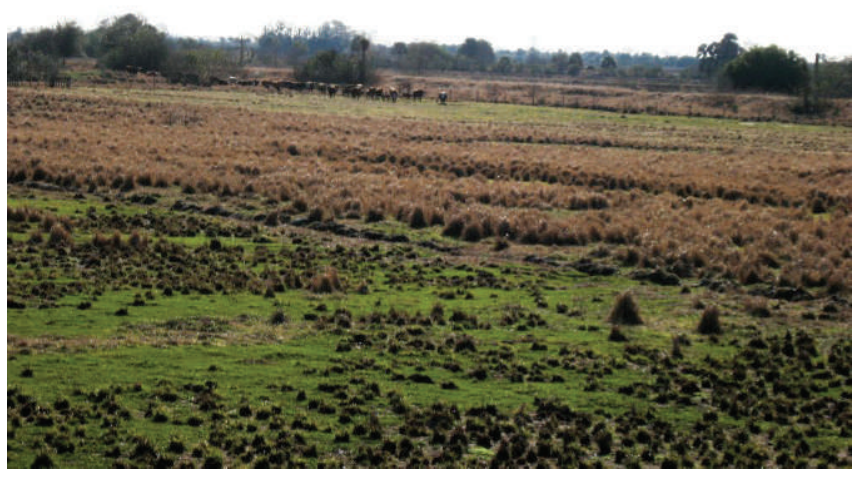

Figure 5. Contrast between the burn plus grazing, mow plus grazing, and control treatments. Photo also shows the green-up of the bahiagrass with some indication of the burned-off smutgrass. 
Table 2. Effect of defoliation by grazing treatments on smutgrass plant density

\begin{tabular}{|c|c|c|c|c|}
\hline Treatment & 23 November 2009 & 15 December 2010 & 30 November 2011 & 19 December 2012 \\
\hline & \multicolumn{4}{|c|}{ Number of plants per quadrat ${ }^{*}$} \\
\hline Control & 4.5 at & $4.0 \mathrm{a}$ & $5.1 \mathrm{a}$ & $5.0 \mathrm{a}$ \\
\hline Mow & $5.5 \mathrm{a}$ & $4.8 \mathrm{a}$ & $5.1 \mathrm{a}$ & $5.2 \mathrm{a}$ \\
\hline \multirow[t]{2}{*}{ Burn } & $2.3 \mathrm{~b}$ & $3.3 \mathrm{a}$ & $3.2 \mathrm{a}$ & $3.9 \mathrm{a}$ \\
\hline & \multicolumn{4}{|c|}{ Number of plants per ha } \\
\hline Control & $11,250 \mathrm{a}$ & $10,000 \mathrm{a}$ & $12,750 \mathrm{a}$ & $12,500 \mathrm{a}$ \\
\hline Mow & $13,750 \mathrm{a}$ & $12,000 \mathrm{a}$ & $12,750 \mathrm{a}$ & $13,000 \mathrm{a}$ \\
\hline Burn & $5,750 \mathrm{~b}$ & $8,250 \mathrm{a}$ & $8,000 \mathrm{~b}$ & $9,750 \mathrm{~b}$ \\
\hline
\end{tabular}

Table 3. Effect of defoliation by grazing treatments on smutgrass plant size measured as plant circumference $(\mathrm{cm})$ and area occupied by plant $\left(\mathrm{cm}^{2}\right)$

\begin{tabular}{|c|c|c|c|c|}
\hline Treatment & 23 November 2009 & 15 December 2010 & 30 November 2011 & 19 December 2012 \\
\hline & \multicolumn{4}{|c|}{ Smutgrass circumference $(\mathrm{cm})$} \\
\hline Control & $58.8 a^{*}$ & $48.4 \mathrm{a}$ & $35.8 \mathrm{a}$ & $38.1 \mathrm{a}$ \\
\hline Mow & $50.6 \mathrm{a}$ & $38.9 \mathrm{~b}$ & $32.3 \mathrm{a}$ & $36.5 \mathrm{a}$ \\
\hline \multirow[t]{2}{*}{ Burn } & $56.8 \mathrm{a}$ & $13.8 \mathrm{c}$ & $17.9 \mathrm{~b}$ & $29.8 \mathrm{a}$ \\
\hline & \multicolumn{4}{|c|}{ Area occupied by smutgrass $\left(\mathrm{cm}^{2}\right)$} \\
\hline Control & $3,466 \mathrm{a}$ & $2,344 \mathrm{a}$ & 1,521 a & $1,660 \mathrm{a}$ \\
\hline Mow & $2,512 \mathrm{a}$ & $1,581 b$ & $1,157 \mathrm{a}$ & $1,522 \mathrm{a}$ \\
\hline Burn & $3,030 \mathrm{a}$ & $296 \mathrm{c}$ & $369 \mathrm{~b}$ & $1,206 a$ \\
\hline
\end{tabular}




\section{Challenges}

We encountered three major challenges as we conducted this project. Each of these might have affected the outcome in some manner.

1) Grazing management posed a great challenge. We had envisioned that the Unit Manager of the ranch would be onboard throughout the project. This did not occur because two of the Unit Managers took promotions to other positions. These changes affected the time, timing, and intensity of the grazing events.

2) Using the GPS equipment to locate the points also posed some challenges. Because the site was on a working ranch, we could not leave any permanent markers for each quadrat. Therefore we relied on the GPS units to locate the points. We believe they did a good job because we were able to go directly to most pin flags from previous years. However, there is an error associated with the placement of the sample frames.

3) Measuring the plants also posed a challenge. The first year posed the greatest challenge. In the control and mowed treatments, it was often hard to tell where one plant ended and the next plant began. It is possible that this might have skewed the statistics. The burned treatments provided a different challenge. In the burned treatments, many of the plants might have been completely consumed by the fire. This means that the number of plants measured in the first year might be lower than what was actually on the site. The large increase in the number of plants in the first year might be the result of this.

\section{Smutgrass Plant Density and Size}

After 1, 2, or 3 years of imposing treatment, plant number did not decrease for the different treatments (Table 2). In defoliated areas, smutgrass plant population remained the same for mow treatments but for burn treatment increased at the end of 3 years by approximately $25 \%$.

In contrast to plant number, smutgrass plant size measured by plant circumference and area occupied showed that it was affected by burning plus grazing treatment. Although in burned pastures the population had a slight increase in number, the size of the plants was significantly reduced (Table 3 ). After 1 year, the smutgrass population in burn areas was reduced to one-third of mow treatment; after 2 years, the population had increased to about half of mow treatments; and by the third year, the population was about $80 \%$ of mow treatments.

\section{Conclusions}

In our case study, we found that pasture burning, followed by high-density rotational stocking: i) significantly reduced the size of smutgrass plants; ii) provided an effective method to slow the invasion rate; and iii) reduced the area occupied by smutgrass, allowing desirable forage grasses to fill the bare spots. After 3 years of defoliation and grazing, prescribed burning will likely be required to continue control of smutgrass in bahiagrass/limpograss pastures.

\section{References}

1. Mislevy, P., And W. L. Currey. 1980. Smutgrass (Sporobolus poiretii) control in South Florida. Weed Science 28:316-320.

2. Sellers, B., J. A. Ferrell, and J. J. Mullahey. 2011 Smutgrass Control in Perennial Grass Pastures. EDIS SS-AGR-18. University of Florida IFAS Extension. Available at: http://edis. ifas.ufl.edu/aa261. Accessed 26 August 2013.

3. Smith, J., A. W. Cole, And V. H. Watson. 1974. Selective smutgrass control and forage quality response in bermudagrassdallisgrass pastures. Agronomy Journal 66:424-426.

4. Lemus, R., M. J. Mowdy, And A. Davis. 2013. Herbicide evaluation for smutgrass control using the weed wiper method. Journal of the National Association of County Agricultural Agents 6 (1). Online. Available at: http://www.nacaa.com/journal/index. php?jid=229. Accessed 26 August 2013.

5. Ferrell, J. A. and J. Mullahey. 2006. Effect of mowing and hexazinone application on giant smutgrass (Sporobolus indicus var. pyramidalis) control. Weed Science 20:90-94.

6. Mullahey, J. J. 2000. Evaluating grazing management systems to control giant smutgrass (Sporobolus indicus var. pyramidalis). Proceedings of the Southern Weed Science Society 53:59. [Abstract]

7. USDA-NRCS. 2013. Forage Suitability Group number 155XB241FL, Sandy Over Loamy Soils on Flats of Hydric or Mesic Lowlands. Available at: http://efotg.sc.egov.usda.gov/references/ public/FL/FSG_MLRA_155XB241FL.pdf. Accessed 26 August 2013.

Authors are Agriculture Agent, Brevard County, University of Florida, Gainesville,FL 32606, USA, jwalter@ufl.edu (Walter); Forage Specialist, Agronomy Dept, University of Florida, Gainesville, FL 32611, USA (Newman); Agriculture Agent, Volusia County, University of Florida, Gainesville, FL 32606, USA (Gamble); Agriculture Agent, Orange and Seminole counties, University of Florida, Gainesville, FL 32606, USA (Mudge); Rangeland Management Specialist, USDA Natural Resources Conservation Service, Kissimmee, FL 34744, USA (Deal); Graduate Student, Agronomy Dept, University of Florida, Gainesville, FL 32611, USA (Baseggio); and Agriculture Agent, Osceola County, University of Florida, Gainesville, FL 32606, USA (Fluke). Funding for this project was provided by the University of Florida Institute of Food and Agricultural Science (UF-IFAS) and the Florida Grazing Lands Conservation Coalition (FGLC). In-kind support was provided by Deseret Cattle and Citrus, Brevard County Extension Service, Orange County Extension Service, Osceola County Extension Service, Volusia County Extension Service, Osceola County Soil and Water Conservation District, and the USDA Natural Resources Conservation Service. 